\title{
Correction to: e-Pharmacophore model-guided design of potential DprE1 inhibitors: synthesis, in vitro antitubercular assay and molecular modelling studies
}

\author{
Avinash Kumar ${ }^{1,2,3} \cdot$ Revathi Rajappan $^{1,2,3} \cdot$ Suvarna G. Kini ${ }^{1,4} \cdot$ Ekta Rathi $^{1,2,3} \cdot$ Sriram Dharmarajan ${ }^{1,2,3}$. \\ K. Sreedhara Ranganath Pai ${ }^{1,2,3}$
}

Published online: 5 July 2021

(c) The Author(s) 2021

\section{Correction to: Chemical Papers \\ https://doi.org/10.1007/s11696-021-01743-3}

In this article, the affiliation numbers of the authors were superscripted incorrectly and given as

Avinash Kumar ${ }^{1,2,3} \cdot$ Revathi Rajappan ${ }^{1,2,3}$. Suvarna G.

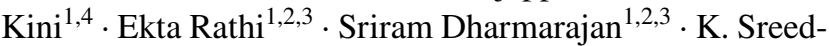
hara Ranganath Pai ${ }^{1,2,3}$

It should have been

Avinash Kumar ${ }^{1} \cdot$ Revathi Rajappan $^{1} \cdot$ Suvarna G. Kini ${ }^{1,4}$ - Ekta Rathi ${ }^{1}$. Sriram Dharmarajan ${ }^{2} \cdot$ K. Sreedhara Ranganath $\mathrm{Pai}^{3}$.

The original article has been corrected.

The original article can be found online at https://doi.org/10.1007/ s11696-021-01743-3.

Suvarna G. Kini

suvarna.gk@manipal.edu

1 Department of Pharmaceutical Chemistry, Manipal College of Pharmaceutical Sciences, Manipal Academy of Higher Education, Manipal, India

2 Department of Pharmacy, Birla Institute of Technology \& Science-Pilani, Hyderabad Campus, Jawahar Nagar, Hyderabad, India

3 Department of Pharmacology, Manipal College of Pharmaceutical Sciences, Manipal Academy of Higher Education, Manipal, India

4 Manipal Mc Gill Centre for Infectious Diseases, Prasanna School of Public Health, Manipal Academy of Higher Education, Manipal, Karnataka 576104, India
Open Access This article is licensed under a Creative Commons Attribution 4.0 International License, which permits use, sharing, adaptation, distribution and reproduction in any medium or format, as long as you give appropriate credit to the original author(s) and the source, provide a link to the Creative Commons licence, and indicate if changes were made. The images or other third party material in this article are included in the article's Creative Commons licence, unless indicated otherwise in a credit line to the material. If material is not included in the article's Creative Commons licence and your intended use is not permitted by statutory regulation or exceeds the permitted use, you will need to obtain permission directly from the copyright holder. To view a copy of this licence, visit http://creativecommons.org/licenses/by/4.0/.

Publisher's Note Springer Nature remains neutral with regard to jurisdictional claims in published maps and institutional affiliations. 